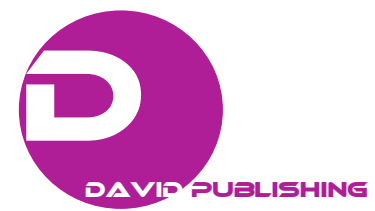

\title{
Obtaining New Potato Cultivars with Late Blight Resistance and Adapted to Climate Change Using Participatory Varietal Selection
}

\author{
Noemí Zúñiga ${ }^{1}$, Manuel Gastelo², Carolina Bastos² Jhercy Reyes $^{3}$, Edson Alania ${ }^{3}$ and Evelin Ninalaya ${ }^{4}$ \\ 1. National Root and Tuberous Program, National Institute of Agricultural Innovation, Huancayo 1200, Perú \\ 2. Genetics, Genomic and Crop Improvement Science Division, International Potato Center-CIP, P.O. Box 1558, Lima12, Peru \\ 3. Faculty of Agricultural Sciences, Professional Academic School of Agronomic Engineering, National University Hermilio Valdizan, \\ Huánuco 10003, Perú
}

4. Agronomy Faculty, National University of the Center of Peru, Huancayo 12006, Perú

\begin{abstract}
The potato crop in Peru is the main income and food source for the smallholder of the highland grower of the Peruvian Andes. For urban population, it represents one of the main components of the food basket and for commercial intermediaries. It is the main brokerage product considering its volume and value. To facilitate the adoption and diffusion of new potato cultivars after its release, adequate methodologies are necessary to apply during the process of evaluation and selection. One of these methodologies is called participatory varietal selection (PVS). The objective of this study was to identify new potato cultivars and/or genotypes with resistance or tolerance to adverse effects of climate change applying PVS, in order to obtain new varieties with acceptable economic yields. In this way potato growers of the Peruvian highland Andes should benefit through the improvement of their economic status, food security and overall life quality. During 2016-2017, three potato clones (CIP393079.4, CIP387096.2 and CIP396034.268) and two commercial varieties (Unica, Canchan) were evaluated at eight Peruvian locations in three regions (Huánuco, Junín and Huancavelica). Data were analyzed using a randomized complete block design, with three replications. Main criteria for selection were late blight resistance, abundant foliage, drought tolerance, yield and uniform and healthy tubers. In all three regions the three best clones selected were CIP396034.268, CIP393079.4 and CIP387096.2, ranking in first, second and third place, respectively. Men and women selected the same clones, but in a different order. Commercial cultivars ranked 4th and 5th. However, local growers selected Canchan, CIP387096.2 and CIP393079.4 based on appearance, texture and taste tests. The last two clones (CIP387096.2 and CIP393079.4) should be considered for a future release.
\end{abstract}

Key words: Potato, late blight, resistance, climate change, participatory varietal selection.

\section{Introduction}

Potatoes are grown in 97,575 ha of the highlands of Peru, representing $31 \%$ of its total area, in 2018 were planted 330,862 ha, with an average yield of $14.9 \mathrm{t} / \mathrm{ha}$ [1]. Among the main problems of the crop are biotic and abiotic adverse factors. Late blight is the biotic factor that if not controlled can cause a total loss of the crop. Frosts and hail are among the abiotic factors.

Corresponding author: Noemí Zúñiga, Ph.D., research field: potato improvement.

This paper is originally published in Revista Latinoamericana de la Papa $(A L A P)$ in Spanish.
The potato crop is the main income and food source for the Peruvian smallholder located in the highlands. As for urban inhabitants, it represents the main component of the food basket and for middlemen, it is the main commercial product because of its volume and sales value [2].

The release of new improved cultivars has been important in the past, increasing the average yield of the crop. However, these new varieties released by various research centers in Peru during the last years, did not have much acceptance by local growers, and their diffusion has been slow. Many studies have shown 
that the main focus during evaluation and selection of new varieties are aspects linked to agronomic traits such as yield, disease and pest resistance, earliness and others [3]. However, these criteria are frequently established by the researchers and do not integrate preferences by other stakeholders of the food chain, such as tuber taste, skin and flesh color, better price, etc. [4, 5].

For a successful adoption and diffusion of a new variety after its release, especial methodologies are needed to apply during the evaluation and selection process. One of these is called participatory varietal selection (PVS), it can be a great promise in the development of new varieties that respond to technological needs of end users, mainly poor farmers who are not well integrated into a market economy [6]. This method allows all actors of the food value chain participate: growers, technicians, researchers, private and public institutions. They participate during two phenological phases of the crop: flowering and harvest. In this process they actively participate identifying and prioritizing criteria for the selection of a new variety and evaluating different candidate genotypes for future varieties. Besides, the gender equity aspect is also important so that the separate opinions of men and women are taken into consideration for an adequate release and diffusion of a new variety as a final product of PVS.

For the new improved varieties to be easily disseminated and adopted, after their release, it is necessary to apply appropriate methodologies to achieve this purpose. One of these methodologies is the PVS which incorporates all the actors in the potato value chain, considering gender equity, the information obtained from both men and women is very important since the criteria to select a new potato variety could be different [4] and these must be incorporated into breeding programs. Mudege et al. [7] mention that in Ethiopia, farmers did not adopt the new sweet potato varieties because they did not have what they needed.
In the Peruvian high plateau, using the PVS, selected a potato clone with the characteristics desired by the farmers in addition to tuber yield, such as adaptation to low temperature conditions of the high plateau, frost tolerance and quality for processing in tunta, this variety was called INIA 317-Altiplano [8].

In a study on PVS, conducted in communities of the province of Lircay, Huancavelica, Peru, during the growing seasons 2008-2009, 2009-2010, identified as selection criteria at the flowering phase, vigorous plants resistant to late blight and at harvest were large tubers and have good yield, these characteristics were decisive for the choice of genotype released as a new variety, called "Kawsay" [9].

Lately, the effects of climatic change are on the rise, with increasing temperatures, erratic patterns of rain distribution and drought. This situation will create an increased pressure on disease incidence like late blight. One way to face these adverse factors is with the use of new potato varieties with genetic resistance to late blight and tolerance to frosts, drought, heat, etc. The main objective of this study was to identify new potato varieties and/or genotypes using PVS with genetic resistance or tolerance to the effects of climate change, acceptable economic yields that will ensure profitability and food security to improve the living standards of Peruvian highland growers.

\section{Materials and Methods}

During period 2016-2017, three potato clones were evaluated for agronomic attributes: CIP393079.4 (white flower), CIP387096.2 (Shulay), CIP396034.268 [10] and Unica and Canchan cultivars (Table 1). Evaluations were performed in eight localities of three Peruvian regions: Huánuco, Junín and Huancavelica (Table 2). Planting was performed during September and November of 2016 and harvest during March and June of 2017.

A randomized complete block design (RCBD) with three replications of 30 plants each was used. Each 
Table 1 Characteristics of potato genetic material used in the study.

\begin{tabular}{llllll}
\hline Clone/variety & Pedigree & Skin color & Flesh color & Tuber shape & Eye depth \\
\hline CIP387096.2 & CIP382119.17 $\times 575049$ & Cream & Cream & Oval & Superficial \\
CIP393079.4 & CIP387004.13 $\times$ CIP390357.4 & Cream & Cream & Oval & Superficial \\
CIP396034.268 & CIP393042.50 $\times$ CIP393280.64 & Red & Cream & Oblong & Superficial \\
Canchan & & Red & Cream & Round & Intermediate \\
Unica & & Red & Cream & Oblong & Superficial \\
\hline
\end{tabular}

Table 2 Peruvian locations where experiments were conducted.

\begin{tabular}{llllll}
\hline No. & Locality & District & Province & Region & Altitude (masl) \\
\hline 1 & Checche & Pampas & Tayacaja & Huancavelica & 3,300 \\
2 & Churcampa & Churcampa & Churcampa & Huancavelica & 3,262 \\
3 & Santa Ana & El Tambo & Huancayo & Junín & 3,270 \\
4 & Paca & Paca & Jauja & Junín & 3,430 \\
5 & Huasahuasi & Huasahuasi & Tarma & Junín & 3,341 \\
6 & Huarisca & Chupaca & Chupaca & Junín & 3,331 \\
7 & Quechualoma & Churubamba & Huanuco & Huánuco & 2,246 \\
8 & Mayobamba & Chinchao & Huánuco & Huánuco & 2,934 \\
\hline
\end{tabular}

plot had six rows of $9 \mathrm{~m}$ each, from which only the two central rows were harvested in order to eliminate the border effect. Total harvested area of each plot was $18 \mathrm{~m}^{2}$. Row separation distance was $1 \mathrm{~m}$ and plant separation $0.30 \mathrm{~m}$. The evaluation methodology used was the PVS [11]. This methodology is useful and facilitates in the adoption and diffusion of newly released varieties. In the process, all actors in the value chain of the crop participate: growers, agricultural agency technicians, researchers, and public and private institutions of each region. PVS was applied during two phenological phases of the crop: at flowering and at harvest. In each phase, two activities were performed: the first was the identification and prioritization of the criteria for the selection of a new variety; the second was the evaluation of candidate genotypes to select the best three, according to visual appreciation, considering prioritized criteria. Besides, organoleptic tests were performed with tubers of clones under evaluation at harvest to determine appearance, taste and texture. Gender equity was considered, for which separate criteria of selection were recorded for men and women. This was considered important for a successful adoption and diffusion of newly released varieties as a final product of PVS.
Two types of variables were recorded: qualitative and quantitative. Qualitative variables at flowering and harvest were recorded, in which participants of PVS orally expressed which characteristic was more important in order to release a new variety taking into consideration the phenological phase of the crop. Then, criteria were prioritized separately from men and women selecting the three most important criteria. Men participants were handed with corn seeds and women participants with faba bean seeds. They each indicated the most important criteria with three seeds, the second most important with two seeds and the third with one seed. In this way men and women preferences were recorded separately. Then, clones were ranked in both crop phases, for which participants looked over experiment plots and after observing each replication handed over their individual evaluation selecting secretly the best three clones. With this information, preferences were ranked for men and women. Finally, at harvest organoleptic tests were performed to determine taste, texture and appearance of tubers from clones and varieties in each location. For quantitative variables, foliar (leaves, stems, flowers and berries) damage caused by late blight was evaluated. Four to six evaluations at 15-day intervals were performed, 
recording the affected area in percentage for each experimental unit. With this information, area under disease progress curve (AUDPC) was calculated. These values allow to estimate the degree of late blight resistance of genetic material in all localities. A simple analysis of variance (ANOVA) was performed to estimate the late effect in each locality and a combined analysis to estimate this effect in each region. Mean clone comparisons were performed using the Waller/Duncan test $(\alpha=0.05)$. Yield performance was determined counting and weighing harvested tubers previously classified into extra, first, second, third and fourth categories. Tubers were harvested only from the central two rows in order to avoid border effect. With this information yield data were calculated as commercial and total yield as ton/ha for each locality in three regions. Similarly, simple ANOVA was performed for each locality and a combined analysis for each region to determine commercial and total yields per hectare. For mean comparisons, the Waller/Duncan $(\alpha=0.05)$ test was used. Statistical analyses were performed using Statistical Analysis System (SAS) for Windows 9.4, SAS Inc.

\section{Results and Discussion}

The most important criteria identified during PVS in the regions of Huánuco, Huancavelica and Junín were: at flowering phase, in the first place late blight resistance and plants with abundant foliage as a second criterion. Other criteria were: plants with thick stems, big plants and drought tolerance as third, fourth and fifth criteria. These criteria mentioned by potato growers have actual importance, due to increase of rains under climatic change, the pressure of the late blight is increasing, and also due to the increase in temperatures today, this disease can occur at heights of more 4,000 m, where previously it was not a limitation in potato crop. Plants with abundant foliage, thick stems and tall plants are related to higher yields.

When disaggregate the information in the regions, in all regions the main criterion is late blight resistance.
However, under climate change conditions the rain regime is becoming erratic, causing periods of drought, affecting potato cultivation, because of this the growers identify as important the criterion of drought tolerance. In Huancavelica farmers need drought tolerance and big sized plants. This is associated with erratic rain distribution patterns in this region. Big plants are associated to presence of native varieties that are predominant in this area. This information is important for breeders in order to create new cultivars with resistance to late blight and tolerance to drought. When rains are abundant, they create a pressure for increased late blight incidence, but the varieties will show their resistance. When rains are scarce, lack of water will be more important than disease, so drought tolerance should be expressed (Fig. 1).

At harvest, in all regions, the most important criteria were: in the first place, high yield, followed by uniform size tuber and healthy tubers. These criteria are closely related to market demand, final objective of producers in order to get better income and profitability, but in Huánuco tubers must be healthy, this is related to a high late blight pressure in Huánuco affecting tuber quality.

Clones CIP396034.268 and CIP393079.4 ranked first and second in growers' preferences at flowering time in all three regions, followed by Canchan. When the information is disaggregate by gender, men preferred clones CIP396034.268, CIP393079.4 and CIP387096.2 ranking in the first, second and third place, respectively. Women selected the first two clones, followed by Canchan. Probably they did so because they associate this variety to frying and fresh consumption qualities. At harvest, in all three regions clones CIP396034.268, CIP393079.4 and CIP387096.2 were selected, ranking as the first, second and third, respectively. Men and women selected the same clones but in a different ranking as shown in Table 3. Selection criteria favoring these clones probably are due to late blight resistance observation and amount and quality of yield. 


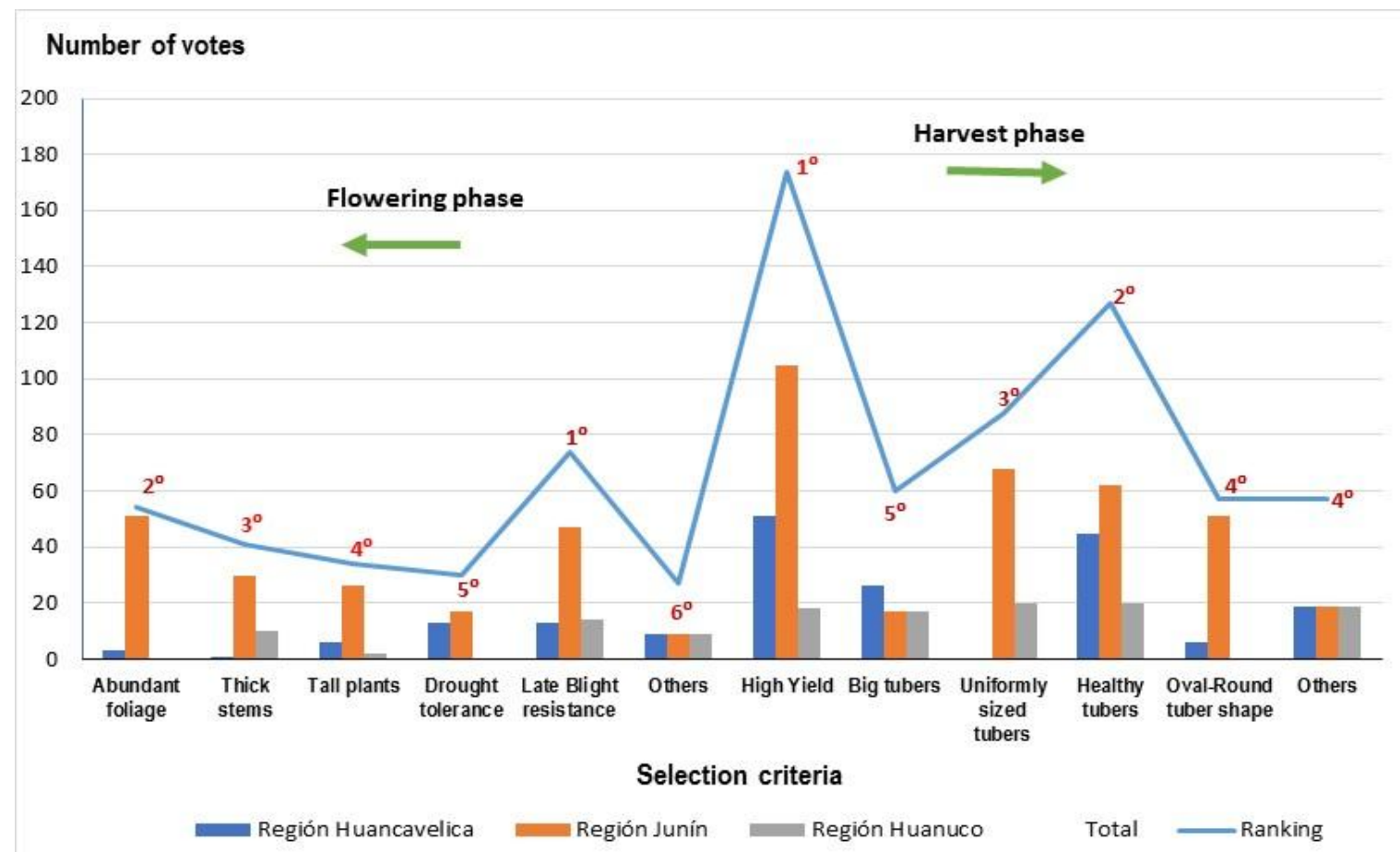

Fig. 1 Selection criteria at flowering and harvest phases across regions in participatory varietal selection (PVS) in Peruvian regions of Huánuco, Huancavelica and Junín, 2016-2017.

Table 3 Ranking of clones and varieties during participatory varietal selection (PVS) in Peruvian locations of Huánuco, Huancavelica and Junín at flowering and harvest phases, 2016-2017.

\begin{tabular}{|c|c|c|c|c|c|c|c|c|c|c|c|c|c|c|c|c|c|c|}
\hline \multirow{2}{*}{ Clones } & \multicolumn{4}{|c|}{ Huancavelica } & \multicolumn{4}{|c|}{ Junín } & \multicolumn{4}{|c|}{ Huánuco } & \multicolumn{3}{|c|}{ Total } & \multicolumn{3}{|c|}{ Ranking } \\
\hline & $\bar{M}$ & $\mathrm{~W}$ & $\mathrm{~T}$ & $\mathrm{R}$ & $\mathrm{M}$ & $\mathrm{W}$ & $\mathrm{T}$ & $\mathrm{R}$ & $M$ & $\mathrm{~W}$ & $\mathrm{~T}$ & $\mathrm{R}$ & $M+W$ & $\mathrm{M}$ & $\mathrm{W}$ & $M+W$ & $M$ & $\mathrm{~W}$ \\
\hline \multicolumn{19}{|l|}{ Flowering } \\
\hline CIP396034.268 & 49 & 40 & 89 & 3 & 144 & 289 & 433 & 2 & 90 & 21 & 111 & 2 & 633 & 283 & 350 & 1 & 1 & 2 \\
\hline Unica & 58 & 73 & 131 & 1 & 60 & 95 & 155 & 5 & 26 & 20 & 46 & 4 & 332 & 144 & 188 & 5 & 5 & 5 \\
\hline Canchan & 49 & 67 & 116 & 2 & 92 & 194 & 286 & 3 & 18 & 15 & 33 & 5 & 435 & 159 & 276 & 3 & 4 & 3 \\
\hline CIP387096.2 & 22 & 32 & 54 & 5 & 78 & 137 & 215 & 4 & 91 & 36 & 127 & 1 & 396 & 191 & 205 & 4 & 3 & 4 \\
\hline CIP393079.4 & 35 & 44 & 79 & 4 & 155 & 293 & 448 & 1 & 64 & 21 & 85 & 3 & 612 & 254 & 358 & 2 & 2 & 1 \\
\hline \multicolumn{19}{|l|}{ Harvest } \\
\hline CIP396034.268 & 91 & 32 & 123 & 2 & 186 & 244 & 430 & 1 & 59 & 48 & 107 & 4 & 660 & 336 & 324 & 1 & 2 & 1 \\
\hline Unica & 74 & 33 & 107 & 3 & 112 & 172 & 284 & 4 & 93 & 27 & 120 & 3 & 511 & 279 & 232 & 4 & 4 & 4 \\
\hline Canchan & 71 & 24 & 95 & 5 & 69 & 156 & 225 & 5 & 27 & 10 & 37 & 5 & 357 & 167 & 190 & 5 & 5 & 5 \\
\hline CIP387096.2 & 56 & 41 & 97 & 4 & 137 & 189 & 326 & 3 & 95 & 56 & 151 & 1 & 574 & 288 & 286 & 3 & 3 & 3 \\
\hline CIP393079.4 & 154 & 18 & 172 & 1 & 138 & 218 & 356 & 2 & 66 & 64 & 130 & 2 & 658 & 358 & 300 & 2 & 1 & 2 \\
\hline
\end{tabular}

$\mathrm{M}=$ men, $\mathrm{W}=$ women, $\mathrm{T}=$ total, $\mathrm{R}=$ ranking.

At the Huancavelica region, growers selected during harvest clones CIP393079.4 and CIP39034.268. At Huánuco, they selected clones CIP387096.2 and CIP393079.4 and at Junín they selected clones CIP396034.268, CIP393079.4 and CIP387096.2 in that ranking order, respectively
(Table 3). Results of organoleptic tests performed with growers at harvest, favored Canchan variety and clones CIP387096.2 and CIP39079.4, which presented the best appearance, taste and texture in all three regions. These results confirm consumers' preference for Canchan variety due to its high dry matter content 
and favorable quality for French fry and chip processing, although susceptible to late blight. Clone CIP387096.2 has also good quality characteristics for French fry processing, with the comparative advantage that is late blight resistant and it will be released as a new variety. At the Huancavelica region, Canchan and Unica were the best after organoleptic tests, and clone CIP387096.2 followed them. At Junín and Huánuco, Canchan variety and clones CIP387096.2 and CIP393079.4 were the best in that order. This shows again the good attributes of clone CIP387096.2 which will be released as a new variety, taking into consideration that Canchan and Unica varieties are preferred in markets because of their quality. However, when they are planted in the field, they do not resist late blight (Table 4). Clone CIP386034.268 did not show good organoleptic characteristics, despite being selected by growers at harvest as one of the best in agronomic traits and yield.

The ANOVA for late blight resistance using AUDPC, shows significant differences $(\alpha=0.01)$ between clones and varieties in all locations (Table 5).
AUDPC values for resistant materials were low compared to susceptible material which showed high values. The coefficients of variability (CV) were within acceptable ranges, except at the Paca location in Junín. At this site, probably because of climatic conditions, other foliar diseases were present, interfering with late blight evaluations.

The combined ANOVA for AUDPC values in each region shows statistical differences $(\alpha=0.01)$ for clones, and clone $\times$ region interaction. This indicates that the late blight infection levels in clones and varieties had different magnitudes in all three regions (Table 6).

When comparing means with the Waller/Duncan test $(\alpha=0.05)$, clones CIP387096.2, CIP393079.4 and CIP396034.268 were statistically equal in all locations and in average over regions but differed from Canchan and Unica (Table 7). AUDPC values for clones are smaller than Unica and Canchan varieties at Huanuco, Junin and Huancavelica. In Huancavelica the clones were less affected by the late blight, probably because of the altitude of the region, the pressure of the disease is low, the opposite happens in Huanuco

Table 4 Organoleptic test for clones and varieties during PVS for tuber appearance, taste and texture in Peruvian locations of Huancavelica, Huánuco and Junín, 2016-2017.

\begin{tabular}{|c|c|c|c|c|c|c|c|c|c|c|c|c|c|c|c|c|c|c|c|c|}
\hline \multirow{2}{*}{ Clones } & \multicolumn{5}{|c|}{ Huancavelica } & \multicolumn{5}{|c|}{ Junín } & \multicolumn{5}{|c|}{ Huánuco } & \multicolumn{5}{|c|}{ Total } \\
\hline & $\mathrm{AP}$ & TST & TEXT & Total & $\mathrm{R}$ & $\mathrm{AP}$ & TST & TEXT & Total & $\mathrm{R}$ & $\mathrm{AP}$ & TST & TEXT & Total & $\mathrm{R}$ & AP & TST & TEXT & Total & $\mathrm{R}$ \\
\hline CIP396034.268 & 115 & 96 & 77 & 288 & 4 & 120 & 107 & 93 & 320 & 5 & 79 & 77 & 69 & 225 & 4 & 314 & 280 & 239 & 833 & 5 \\
\hline Unica & 123 & 111 & 93 & 327 & 2 & 125 & 118 & 89 & 332 & 4 & 77 & 81 & 53 & 211 & 5 & 325 & 310 & 235 & 870 & 4 \\
\hline Canchan & 127 & 103 & 117 & 347 & 1 & 151 & 152 & 116 & 419 & 1 & 85 & 85 & 77 & 247 & 2 & 363 & 340 & 310 & 1,013 & 1 \\
\hline CIP387096.2 & 131 & 115 & 79 & 325 & 3 & 153 & 144 & 108 & 405 & 2 & 91 & 89 & 72 & 252 & 1 & 375 & 348 & 259 & 982 & 2 \\
\hline CIP393079.4 & 113 & 91 & 77 & 281 & 5 & 135 & 120 & 91 & 346 & 3 & 87 & 85 & 57 & 229 & 3 & 335 & 296 & 225 & 856 & 3 \\
\hline
\end{tabular}

$\mathrm{AP}=$ appearance, $\mathrm{TST}=$ taste, $\mathrm{TEXT}=$ texture, $\mathrm{R}=$ ranking .

Table 5 Analysis of variance (ANOVA) for late blight resistance (area under disease progress curve (AUDPC) values) in eight localities, Huancavelica, Huánuco and Junín, Peru, 2016-2017.

\begin{tabular}{|c|c|c|c|c|c|c|c|c|c|}
\hline \multirow{3}{*}{$\begin{array}{l}\text { Sources of } \\
\text { variation }\end{array}$} & \multirow{3}{*}{ df } & \multicolumn{8}{|c|}{ Mean squared } \\
\hline & & \multicolumn{2}{|c|}{ Huanuco } & \multicolumn{2}{|c|}{ Huancavelica } & \multicolumn{4}{|c|}{ Junin } \\
\hline & & Mayobamba & Quechualoma & Checche & Churcampa & Huasahuasi & Paca & Huarisca & Santa Ana \\
\hline Repetitions & 2 & $2,029 \cdot 07^{\mathrm{ns}}$ & $46,336.27^{\text {ns }}$ & $48,063.80^{\mathrm{ns}}$ & $1,363 \cdot 27^{\mathrm{ns}}$ & $140,612.87^{\mathrm{ns}}$ & $9,280 \cdot 27^{\mathrm{ns}}$ & $11,391.80^{\mathrm{ns}}$ & $119,652.87^{\mathrm{ns}}$ \\
\hline Clones & 4 & $18,174,003.77^{* *}$ & $814,290.57^{* *}$ & $679,531.77^{* *}$ & $439,295.17^{* *}$ & $18,635,380.27^{* *}$ & $483,353.93^{* *}$ & $122,805.60^{* *}$ & $1,676,301.57^{* *}$ \\
\hline Error & 8 & $80,628.07$ & $26,173.77$ & $19,031.47$ & $1,610.77$ & $73,378.62$ & $23,045.68$ & $5,066.55$ & $42,088.12$ \\
\hline$\overline{\mathrm{CV} \%}$ & & 12.97 & 29.51 & 27.03 & 12.41 & 14.12 & 39.30 & 31.32 & 28.31 \\
\hline
\end{tabular}

\footnotetext{
***atistically significant at $\alpha=0.01 ; \mathrm{ns}=$ not statistically significant; $\mathrm{df}=$ degrees of freedom.
} 
Table 6 Combined ANOVA for late blight resistance (AUDPC values) over localities in Huancavelica, Huánuco and Junín, Peru, 2016-2017.

\begin{tabular}{lllllll}
\hline \multirow{2}{*}{ Sources of variation } & df & \multicolumn{5}{c}{ Mean squared } \\
\cline { 3 - 7 } & & Huanuco & df & Huancavelica & df & Junin \\
\hline Regions & 1 & $20,193,325.63^{* *}$ & 1 & $261,893.63^{* *}$ & 3 & $8,778,665.39^{* *}$ \\
Repetitions/Regions & 4 & $24,182.67^{\text {ns }}$ & 4 & $24,713.53^{*}$ & 8 & $70,234.45^{*}$ \\
Clones & 4 & $13,225,745.45^{* *}$ & 4 & $1,080,961.38^{* *}$ & 4 & $11,040,977.98^{* *}$ \\
Clones $\times$ Regions & 4 & $5,762,548.88^{* *}$ & 4 & $37,865.55^{*}$ & 12 & $3,292,287.80^{* *}$ \\
Combined error & 16 & $53,400.92$ & 16 & $10,321.12$ & 32 & $35,894.70$ \\
\hline CV \% & & 16.88 & 24.37 & 23.28 \\
\hline
\end{tabular}

*** statistically significant at $\alpha=0.01 ;{ }^{*}$ statistically significant at $\alpha=0.05 ; \mathrm{ns}=$ not statistically significant; $\mathrm{df}=\mathrm{degrees}$ of freedom.

Table 7 Mean comparisons using the Waller/Duncan test $(\alpha=0.01)$ for late blight resistance (AUDPC values) for clones and varieties in eight localities, Huancavelica, Huánuco and Junín, Peru, 2016-2017.

\begin{tabular}{lllllllll}
\hline \multirow{2}{*}{ Clones } & \multicolumn{3}{c}{ Huanuco } & \multicolumn{3}{c}{ Huancavelica } & \multicolumn{3}{c}{ Junin } \\
\cline { 2 - 8 } & Mayobamba & Quechualoma & Checche & Churcampa & Huasahuasi & Paca & Huarisca & Santa Ana \\
\hline CIP387096.2 & $326^{\mathrm{a} *}$ & $171^{\mathrm{a}}$ & $165^{\mathrm{a}}$ & $98^{\mathrm{a}}$ & $94^{\mathrm{a}}$ & $89^{\mathrm{a}}$ & $86^{\mathrm{a}}$ & $223^{\mathrm{a}}$ \\
CIP393079.4 & $484^{\mathrm{a}}$ & $204^{\mathrm{a}}$ & $183^{\mathrm{a}}$ & $103^{\mathrm{a}}$ & $128^{\mathrm{a}}$ & $103^{\mathrm{a}}$ & $58^{\mathrm{a}}$ & $205^{\mathrm{a}}$ \\
CIP396034.268 & $366^{\mathrm{a}}$ & $160^{\mathrm{a}}$ & $188^{\mathrm{a}}$ & $78^{\mathrm{a}}$ & $105^{\mathrm{a}}$ & $94^{\mathrm{a}}$ & $98^{\mathrm{a}}$ & $120^{\mathrm{a}}$ \\
Canchan & $4,854^{\mathrm{b}}$ & $1,275^{\mathrm{c}}$ & $808^{\mathrm{b}}$ & $363^{\mathrm{b}}$ & $4,252^{\mathrm{b}}$ & $743^{\mathrm{b}}$ & $481^{\mathrm{b}}$ & $1,425^{\mathrm{b}}$ \\
Unica & $4,915^{\mathrm{b}}$ & $930^{\mathrm{b}}$ & $1,208^{\mathrm{c}}$ & $975^{\mathrm{c}}$ & $5,014^{\mathrm{c}}$ & $899^{\mathrm{b}}$ & $412^{\mathrm{b}}$ & $1,650^{\mathrm{b}}$ \\
\hline
\end{tabular}

*Clones and varieties with the same letter are statically similar.

and Junin where environmental conditions and altitude are more favorable to have increased pressure from late blight (Table 8).

The ANOVA for commercial tuber yield per hectare shows significant statistical differences for clones in all locations $(\alpha=0.05)$. In Churcampa and Huasahuasi locations, these differences were even greater $(\alpha=0.01)$ (Table 9). The CV was within a normal range at all locations.

The combined ANOVA for regions shown in Table 10 indicates significant statistical differences for regions, clones and clones $\times$ region interaction. This is as a result of clone commercial yield differences between clones and varieties. The interaction clones $x$ region may be explained because of different environmental conditions and crop management in each region. $\mathrm{CV}$ values were within acceptable ranges.

Mean comparisons using the Waller/Duncan test ( $\alpha=0.05$ ) show that the commercial tuber yield per hectare of the clones was different across localities, probably due to different environmental characteristics at each site. The clone
CIP396034.268 was statistically different from the rest of the clones and varieties in Huasahuasi and Santa Ana in Junin and in Churcampa, Huancavelica with $35.54,28.48$ and $76.38 \mathrm{t} / \mathrm{ha}$, respectively. In the other locations its yield was in the range of $8.58 \mathrm{t} / \mathrm{ha}$ to $49.65 \mathrm{t} / \mathrm{ha}$. In localities from Huánuco, its commercial tuber yield was lower than in the other locations, probably due to excessive rains and high pressure of late blight (Table 11). The commercial tuber yields of clones CIP393079.4 and CIP387096.2 and the Canchan and Unica varieties, were variable across the localities.

In Huanuco, the average yield of commercial tubers of the Unica variety was statistically equal to the three clones under study but different from the Canchan variety, probably because in the localities of this region, the late blight pressure is high and the resistance to late blight of the clones and the susceptibility of the Canchan variety $(\alpha=0.05)$. In Huancavelica region, the clone CIP396034.268 yielded more than the rest of clones and varieties and similar results were obtained at the Junin region, but 
Table 8 Mean test comparison using the Waller/Duncan test $(\alpha=0.01)$ for AUDPC values for clones and varieties over localities in Huancavelica, Huánuco and Junín, Peru, 2016-2017.

\begin{tabular}{llll}
\hline Clones & Huánuco & Huancavelica & Junín \\
\hline CIP387096.2 & $249^{\mathrm{a}^{*}}$ & $131^{\mathrm{a}}$ & $123^{\mathrm{a}}$ \\
CIP393079.4 & $344^{\mathrm{a}}$ & $143^{\mathrm{a}}$ & $123^{\mathrm{a}}$ \\
CIP396034.268 & $263^{\mathrm{a}}$ & $133^{\mathrm{a}}$ & $104^{\mathrm{a}}$ \\
Unica & $3,065^{\mathrm{b}}$ & $1,091^{\mathrm{c}}$ & $1,994^{\mathrm{c}}$ \\
Canchan & $2,923^{\mathrm{b}}$ & $586^{\mathrm{b}}$ & $1,725^{\mathrm{b}}$ \\
\hline
\end{tabular}

*Clones and varieties with the same letter are statically similar.

Table 9 ANOVA for commercial tuber yield per hectare in eight localities, Huancavelica, Huánuco and Junín, Peru, 2016-2017.

\begin{tabular}{|c|c|c|c|c|c|c|c|c|c|}
\hline \multirow{3}{*}{$\begin{array}{l}\text { Sources of } \\
\text { Variation }\end{array}$} & \multirow{3}{*}{ df } & \multicolumn{8}{|c|}{ Mean square } \\
\hline & & \multicolumn{2}{|c|}{ Huanuco } & \multicolumn{2}{|c|}{ Huancavelica } & \multicolumn{4}{|c|}{ Junin } \\
\hline & & Mayobamba & Quechualoma & Checche & Churcampa & Huasahuasi & Paca & Huarisca & Santa Ana \\
\hline Repetitions & 2 & $2.54^{\mathrm{ns}}$ & $0.61^{\mathrm{ns}}$ & $74.40^{*}$ & $191.40^{\mathrm{ns}}$ & $18.38^{\text {ns }}$ & $79.96^{\mathrm{ns}}$ & $79.96^{\text {ns }}$ & $6.02^{\mathrm{ns}}$ \\
\hline Clones & 4 & $16.47^{*}$ & $20.54^{*}$ & $53.35^{*}$ & $942.00^{* * *}$ & $317.18^{* *}$ & $104.69^{*}$ & $151.30^{*}$ & $113.31^{*}$ \\
\hline Error & 8 & 3.67 & 8.67 & 19.16 & 173.80 & 8.84 & 26.68 & 58.46 & 18.53 \\
\hline $\mathrm{CV} \%$ & & 25.94 & 27.81 & 15.70 & 26.10 & 8.84 & 12.41 & 29.57 & 22.76 \\
\hline
\end{tabular}

statistically significant at $\alpha=0.01$; statistically significant at $\alpha=0.05 ; \mathrm{ns}=$ not statistically significant; df $=$ degrees of freedom.

Table 10 Combined ANOVA for commercial tuber yield per hectare over localities in Huancavelica, Huánuco and Junín, Peru, 2016-2017.

\begin{tabular}{lllllll}
\hline \multirow{2}{*}{ Sources of variation } & df & \multicolumn{5}{c}{ Mean square } \\
\cline { 3 - 6 } & & Huanuco & df & Huancavelica & df & Junin \\
\hline Regions & 1 & $76.86^{* *}$ & 1 & $3,839.75^{* *}$ & 3 & $1,471.54^{* *}$ \\
Repetitions/Regions & 4 & $1.57^{\mathrm{ns}}$ & 4 & $132.90^{\mathrm{ns}}$ & 8 & $39.50^{\mathrm{ns}}$ \\
Clones & 4 & $16.92^{*}$ & 4 & $638.70^{* *}$ & 4 & $501.95^{* *}$ \\
Clones $\times$ Regions & 4 & $20.09^{*}$ & 4 & $356.65^{*}$ & 12 & $61.51^{*}$ \\
Combined error & 16 & 6.17 & 16 & $356.65^{*}$ & & 28.13 \\
\hline CV\% & & 27.64 & 25.06 & & 19.35 \\
\hline
\end{tabular}

*** statistically significant at $\alpha=0.01 ;{ }^{*}$ statistically significant at $\alpha=0.05 ; \mathrm{ns}=$ not statistically significant; $\mathrm{df}=\mathrm{degrees}$ of freedom.

Table 11 Mean comparisons using the Waller/Duncan test $(\alpha=0.05)$ for commercial tuber yield per hectare (t/ha) in eight localities, Huancavelica, Huánuco and Junín, Peru, 2016-2017.

\begin{tabular}{lllllllll}
\hline \multirow{2}{*}{ Clones } & \multicolumn{3}{c}{ Huanuco } & \multicolumn{3}{c}{ Huancavelica } & \multicolumn{3}{c}{ Junin } \\
\cline { 2 - 8 } & Mayobamba & Quechualoma & Checche & Churcampa & Huasahuasi & Paca & Huarisca & Santa Ana \\
\hline CIP387096.2 & $9.51^{a^{\mathrm{a}}}$ & $10.75^{\mathrm{ab}}$ & $27.74^{\mathrm{ab}}$ & $31.83^{\mathrm{c}}$ & $28.18^{\mathrm{b}}$ & $36.10^{\mathrm{b}}$ & $20.14^{\mathrm{ab}}$ & $17.68^{\mathrm{b}}$ \\
CIP387096.2 & $7.55^{\mathrm{a}}$ & $8.65^{\mathrm{ab}}$ & $27.24^{\mathrm{ab}}$ & $40.18^{\mathrm{bc}}$ & $27.46^{\mathrm{b}}$ & $46.11^{\mathrm{ab}}$ & $29.62^{\mathrm{ab}}$ & $15.81^{\mathrm{b}}$ \\
CIP396034.268 & $8.58^{\mathrm{a}}$ & $8.00^{\mathrm{b}}$ & $34.98^{\mathrm{a}}$ & $76.38^{\mathrm{a}}$ & $35.54^{\mathrm{a}}$ & $49.65^{\mathrm{a}}$ & $36.37^{\mathrm{a}}$ & $28.48^{\mathrm{a}}$ \\
Unica & $7.88^{\mathrm{a}}$ & $14.69^{\mathrm{a}}$ & $24.41^{\mathrm{b}}$ & $44.12^{\mathrm{bc}}$ & $12.20^{\mathrm{c}}$ & $38.65^{\mathrm{b}}$ & $19.61^{\mathrm{b}}$ & $20.45^{\mathrm{ab}}$ \\
Canchan & $3.42^{\mathrm{b}}$ & $10.85^{\mathrm{ab}}$ & $25.02^{\mathrm{b}}$ & $60.01^{\mathrm{ab}}$ & $12.86^{\mathrm{c}}$ & $37.66^{\mathrm{b}}$ & $23.54^{\mathrm{ab}}$ & $12.13^{\mathrm{b}}$ \\
\hline
\end{tabular}

*Clones and varieties with the same letter are statically similar.

this clone CIP386034.268 did not show good organoleptic characteristics, despite of being selected by growers at harvest as one of the best in agronomic traits and commercial tuber yield.
The Canchan and Unica varieties presented the highest yields in Huancavelica because these varieties are better adapted to these conditions and the low pressure of the late blight (Table 12, Fig. 2). 
The ANOVA for total tuber yield (t/ha) shows statistical differences for clones at all locations, except in Quechualoma site (Table 13). CV values were within normal ranges.

The combined ANOVA for regions shown in Table 14, indicates significant statistical differences in Huancavelica and Junín for clones and clone $\times$ region interaction. This was because of significant yield differences in clones and varieties tested. The interaction with localities is explained because of different environment and crop management in each location. This was not true for the Huánuco region in which no significant yield differences were detected in these sources of variation. $\mathrm{CV}$ values were within acceptable ranges.

Mean comparisons using the Waller/Duncan test (Table 15), show that total tuber yields varied in all eight locations, due probably to different environmental

Table 12 Mean comparisons using the Waller/Duncan test $(\alpha=0.05)$ for tuber commercial yield per hectare (t/ha) over localities in Huancavelica, Huánuco and Junín, Peru, 2016-2017.

\begin{tabular}{llll}
\hline Clones & Huánuco & Huancavelica & Junín \\
\hline CIP387096.2 & $10.13^{\mathrm{ab}^{*}}$ & $31.20^{\mathrm{c}}$ & $25.53^{\mathrm{c}}$ \\
CIP393079.4 & $8.10^{\mathrm{ab}}$ & $33.71^{\mathrm{bc}}$ & $29.75^{\mathrm{b}}$ \\
CIP396034.268 & $8.29^{\mathrm{ab}}$ & $55.68^{\mathrm{a}}$ & $37.51^{\mathrm{a}}$ \\
Unica & $11.29^{\mathrm{a}}$ & $34.27^{\mathrm{bc}}$ & $22.73^{\mathrm{c}}$ \\
Canchan & $7.14^{\mathrm{b}}$ & $42.51^{\mathrm{b}}$ & $21.55^{\mathrm{c}}$ \\
\hline
\end{tabular}

*Clones and varieties with the same letter are statically similar.

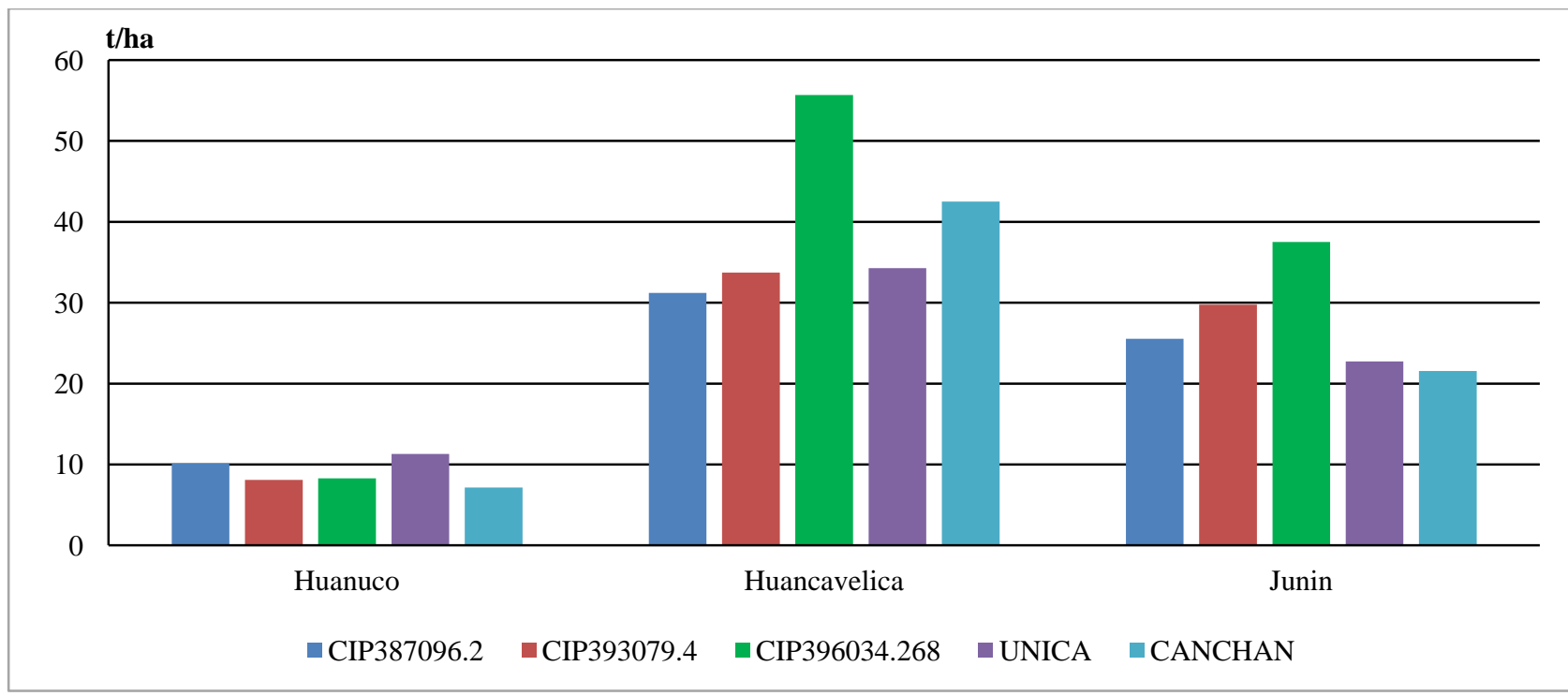

Fig. 2 Commercial tuber yield per hectare in t/ha of potato clones and varieties tested in Huancavelica, Huánuco and Junín, Peru, 2016-2017.

Table 13 ANOVA for total tuber yield per hectare in tons in eight localities, Huancavelica, Huánuco and Junín, Peru, 2016-2017.

\begin{tabular}{|c|c|c|c|c|c|c|c|c|c|}
\hline \multirow{3}{*}{$\begin{array}{l}\text { Sources of } \\
\text { variation }\end{array}$} & \multirow{3}{*}{$\mathrm{df}$} & \multicolumn{8}{|c|}{ Mean square } \\
\hline & & \multicolumn{2}{|c|}{ Huanuco } & \multicolumn{2}{|c|}{ Huancavelica } & \multicolumn{4}{|c|}{ Junin } \\
\hline & & Mayobamba & Quechualoma & Checche & Churcampa & Huasahuasi & Paca & Huarisca & Santa Ana \\
\hline Repetitions & 2 & $2.25^{\mathrm{ns}}$ & $0.54^{\mathrm{ns}}$ & $97.78^{*}$ & $240.45^{\mathrm{ns}}$ & $7.35^{\mathrm{ns}}$ & $74.46^{\mathrm{ns}}$ & $72.25^{\mathrm{ns}}$ & $6.41^{\mathrm{ns}}$ \\
\hline Clones & 4 & $17.10^{*}$ & $16.48^{\mathrm{ns}}$ & $57.15^{*}$ & $1,026.53^{*}$ & $366.93^{* *}$ & $112.83^{*}$ & $166.70^{*}$ & $115.21^{*}$ \\
\hline Error & 8 & 3.46 & 12.32 & 14.89 & 225.29 & 13.24 & 32.88 & 61.25 & 18.88 \\
\hline $\mathrm{CV} \%$ & & 23.11 & 30.36 & 12.14 & 27.67 & 14.89 & 13.13 & 27.82 & 21.93 \\
\hline
\end{tabular}

** statistically significant at $\alpha=0.01$; ${ }^{*}$ statistically significant at $\alpha=0.05 ; \mathrm{ns}=$ not statistically significant; $\mathrm{df}=\mathrm{degrees}$ of freedom. 
Table 14 Combined ANOVA for total tuber yield per hectare in tons in Huancavelica, Huánuco and Junín, $2016-2017$.

\begin{tabular}{lllllll}
\hline \multirow{2}{*}{ Sources of variation } & df & \multicolumn{5}{c}{ Mean square } \\
\cline { 3 - 7 } & & Huanuco & df & Huancavelica & df & Junin \\
\hline Regions & 1 & $92.65^{* *}$ & 1 & $3,784.73^{* * *}$ & 3 & $1,605.68^{* *}$ \\
Repetitions/Regions & 4 & $1.40^{\mathrm{ns}}$ & 4 & $167.61^{\mathrm{ns}}$ & 8 & $40.12^{\mathrm{ns}}$ \\
Clones & 4 & $16.04^{\mathrm{ns}}$ & 4 & $707.60^{* *}$ & 4 & $554.99^{* *}$ \\
Clones $\times$ Regions & 4 & $17.55^{\mathrm{ns}}$ & 4 & $376.08^{*}$ & 12 & $68.90^{*}$ \\
Combined error & 16 & 7.89 & 16 & 120.09 & & 31.56 \\
\hline CV\% & & 28.65 & & 25.47 & 19.37 \\
\hline
\end{tabular}

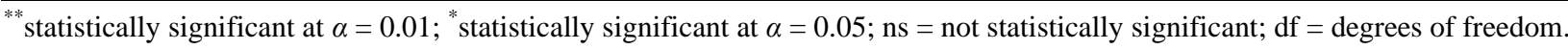

Table 15 Mean comparisons using the Waller/Duncan test $(\alpha=0.05)$ for tuber total yield per hectare (t/ha) in eight locations, Huancavelica, Huánuco and Junín, Peru, 2016-2017.

\begin{tabular}{lllllllll}
\hline \multirow{2}{*}{ Clones } & \multicolumn{3}{c}{ Huanuco } & \multicolumn{3}{c}{ Huancavelica } & \multicolumn{3}{c}{ Junin } \\
\cline { 2 - 8 } & Mayobamba & Quechualoma & Checche & Churcampa & Huasahuasi & Paca & Huarisca & Huarisca \\
\hline CIP387096.2 & $10.07^{\mathrm{a}}$ & $11.96^{\mathrm{a}}$ & $30.57^{\mathrm{b}}$ & $34.61^{\mathrm{b}}$ & $29.54^{\mathrm{a}}$ & $38.68^{\mathrm{b}}$ & $22.21^{\mathrm{ab}}$ & $18.62^{\mathrm{b}}$ \\
CIP393079.4 & $8.36^{\mathrm{a}}$ & $10.24^{\mathrm{a}}$ & $31.72^{\mathrm{ab}}$ & $44.77^{\mathrm{b}}$ & $29.02^{\mathrm{a}}$ & $48.77^{\mathrm{ab}}$ & $33.54^{\mathrm{ab}}$ & $16.69^{\mathrm{b}}$ \\
CIP396034.268 & $9.18^{\mathrm{a}}$ & $8.80^{\mathrm{a}}$ & $39.24^{\mathrm{a}}$ & $81.07^{\mathrm{a}}$ & $37.75^{\mathrm{a}}$ & $51.72^{\mathrm{a}}$ & $38.17^{\mathrm{a}}$ & $29.55^{\mathrm{a}}$ \\
Unica & $8.70^{\mathrm{a}}$ & $15.09^{\mathrm{a}}$ & $28.90^{\mathrm{b}}$ & $46.16^{\mathrm{b}}$ & $12.61^{\mathrm{c}}$ & $40.32^{\mathrm{ab}}$ & $20.95^{\mathrm{b}}$ & $21.15^{\mathrm{ab}}$ \\
Canchan & $3.93^{\mathrm{b}}$ & $11.71^{\mathrm{a}}$ & $28.50^{\mathrm{b}}$ & $64.66^{\mathrm{ab}}$ & $13.25^{\mathrm{c}}$ & $38.84^{\mathrm{b}}$ & $25.76^{\mathrm{ab}}$ & $13.04^{\mathrm{b}}$ \\
\hline
\end{tabular}

*Clones and varieties with the same letter are statically similar.

Table 16 Mean comparisons using the Waller/Duncan test $(\alpha=0.05)$ for total tuber yield per hectare (t/ha) in Huancavelica, Huanuco and Junin, 2016-2017.

\begin{tabular}{llll}
\hline Clones & Huánuco & Huancavelica & Junín \\
\hline CIP387096.2 & $11.02^{\mathrm{a}^{\mathrm{a}}}$ & $32.59^{\mathrm{c}}$ & $27.26^{\mathrm{c}}$ \\
CIP393079.4 & $9.30^{\mathrm{a}}$ & $38.25^{\mathrm{bc}}$ & $32.01^{\mathrm{b}}$ \\
CIP396034.268 & $8.99^{\mathrm{a}}$ & $60.16^{\mathrm{a}}$ & $39.30^{\mathrm{a}}$ \\
Unica & $11.90^{\mathrm{a}}$ & $37.33^{\mathrm{bc}}$ & $23.76^{\mathrm{cd}}$ \\
Canchan & $7.82^{\mathrm{a}}$ & $46.78^{\mathrm{ab}}$ & $22.72^{\mathrm{d}}$ \\
\hline
\end{tabular}

*Clones and varieties with the same letter are statically similar.

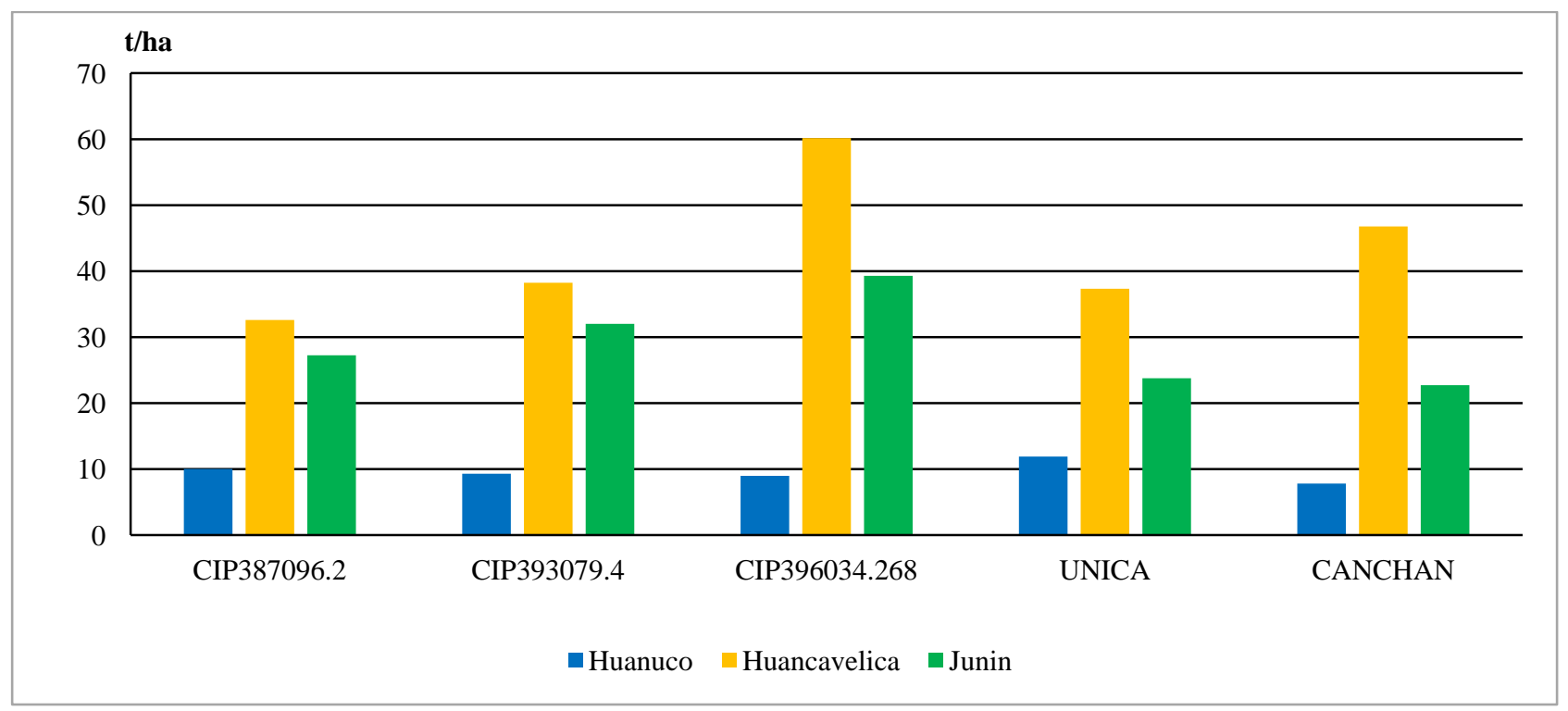

Fig. 3 Total tuber yield per hectare in t/ha of clones and varieties tested in Huancavelica, Huánuco and Junín, $2016-2017$. 
conditions of each region. Total yields at Huánuco were less than the other two regions, probably because of excessive rains and high pressure of late blight as a result of climatic change.

Mean comparisons using the Waller/Duncan test (Table 16) show significant total yield differences between clones and varieties at the Huancavelica and Junín regions. At the Huanuco region, all clones and varieties tested yielded similarly. At the Huancavelica region, clone CIP396034.268 yielded significantly better than the rest of clones and varieties with 60.16 $\mathrm{t} / \mathrm{ha}$. Similarly, at the Junin region this clone yielded better than the rest of clones and varieties, with 39.30 t/ha, followed by CIP393079.4 and CIP387096.2 (Table 16, Fig. 3).

\section{Conclusions}

The three best selection criteria at flowering phase were late blight resistance, abundant foliage and drought tolerance, in that order. At harvest, the best criteria were high tuber yield, tuber size uniformity and healthy appearance of tubers.

At flowering time, the best two clones selected by potato growers using PVS were CIP396034.268 and CIP393079.4.

At harvest, growers in all regions selected clones CIP396034.268, CIP393079.4 and CIP387096.2, in that order. Men and women selected the same three clones but ranking differently.

When selection criteria was based on organoleptic characteristics as tuber appearance, taste and texture, growers in all regions selected clones CIP387096.2 and CIP393079.4.

Clones CIP387096.2, CIP393079.4 and CIP386034.268 were more late blight resistant than Canchan and Unica (actual) varieties in all regions.

After the organoleptic evaluation, high level of late blight resistance and high commercial tuber yield, the clones CIP387096.2 and CIP 393079.4, can be considered for release as new potato varieties in the future.

\section{References}

[1] Peruvian Ministry of Agriculture. 2018 http://sissic.minagri.gob.pe/sissic. (in Spanish)

[2] Egusquiza, R. 2000. The Potato: Production, Transformation and Trading. Lima, Perú: ADEX-AID/MSP, 192. (in Spanish)

[3] Landeo, J. A., Gastelo, M. A., Pacheco, M. A., De Haan, S., Diaz, L., Puente de la Vega, E., and Campesina, C. 2008. "Two New Potato Varieties (Solanum tuberosum ssp. andigena) with Horizontal Resistance to Late Blight Selected by Andean Communities through Participatory Variety Selection." Presented at Potato Science for the Poor; Challenges for the New Millenium, Cusco, Peru.

[4] Cuesta, X., and Andrade, H. 2003. Participatory Potato Improvement in Ecuador. INIAP-PNRT-papa. PREDUZA Quito Ecuador, 139-48. (in Spanish)

[5] Gabriel, J., Herbas, J., Salazar, M., and Thiele, G. 2002. "Technical Manual of Participatory Improvement to Obtain New Potato Varieties." Promotion and Research of Andean Products, Participatory Improvement Project (PROINPA), Bolivia. (in Spanish)

[6] Morris, M. L., and Bellon, M. R. 2004. "Participatory Plant Breeding Research: Opportunities and Challenges for the International Crop Improvement System.' Netherlands Euphytica 136: 21-35.

[7] Mudege, N. N., Mukewa, E., and Amele, A. 2015 Workshop Report: Training on Gender Integrated Potato Participatory Varietal Selection (PVS) in Ethiopia. Addis Ababa, Ethiopia: CIP.

[8] Arcos, J., Gastelo, M., and Holguin, V. 2015. "INIA 317-Altiplano, New Potato Variety with a Good Adaptability to the Altiplano Region of Peru." Latin American Potato Journal 19 (2): 68-75. (in Spanish)

[9] Janampa, A. 2012. "Participatory Selection under the Mother \& Baby Design of 20 Potato Clones Solanum tuberosum spp. andigena (Population B1C5), with Horizontal Resistance to Late Blight (Phytophthora infestans)." Thesis Agronomist, University for Andean Development. (in Spanish)

[10] Centro Internacional de la Papa (International Potato Center). 2014. "Catalogue of Potato Varieties and Advanced Clone.” http://www.cipotato.org/catalogue.

[11] De Haan, S., Salas, E., Fonseca, C., Gastelo, M., Amaya, N., Bastos, C., Hualla, V., and Bonierbale, M. 2017. Participatory Varietal Potato Selection Using the Mother-Baby Design: A Trainer's Guide with a Gender Perspective. Lima, Perú: Internatonal Potato Center, 82 (in Spanish) 